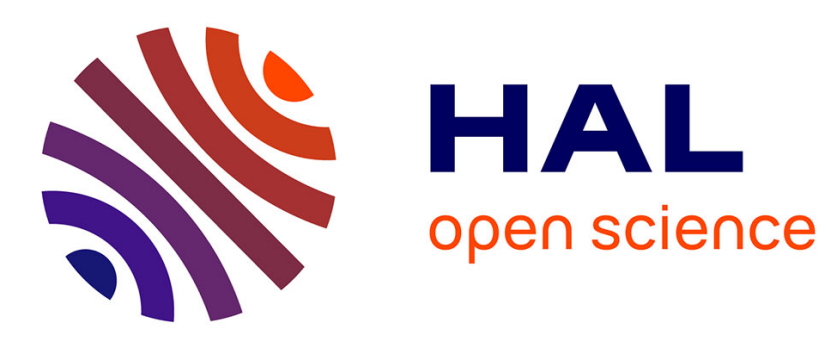

\title{
On-line efficiency optimization of a synchronous reluctance motor
}

Thierry Lubin, Hubert Razik, Abderrezak Rezzoug

\section{To cite this version:}

Thierry Lubin, Hubert Razik, Abderrezak Rezzoug. On-line efficiency optimization of a synchronous reluctance motor. Electric Power Systems Research, 2007, 77, pp.484-493. 10.1016/j.epsr.2006.04.010 . hal-00556410

\section{HAL Id: hal-00556410 https://hal.science/hal-00556410}

Submitted on 4 May 2015

HAL is a multi-disciplinary open access archive for the deposit and dissemination of scientific research documents, whether they are published or not. The documents may come from teaching and research institutions in France or abroad, or from public or private research centers.
L'archive ouverte pluridisciplinaire HAL, est destinée au dépôt et à la diffusion de documents scientifiques de niveau recherche, publiés ou non, émanant des établissements d'enseignement et de recherche français ou étrangers, des laboratoires publics ou privés. 


\title{
On-line efficiency optimization of a synchronous reluctance motor
}

\author{
Thierry Lubin, Hubert Razik, and Abderrezak Rezzoug \\ Groupe de Recherche en Electrotechnique et Electronique de Nancy, GREEN, CNRS-UMR 7037, \\ Université Henri Poincaré, BP 239, 54506 Vandoeuvre-lès-Nancy Cedex, France
}

\begin{abstract}
This paper deals with an on-line optimum-efficiency control of a synchronous reluctance motor drive. The input power minimization control is implemented with a search controller using Fibonacci search algorithm. It searches the optimal reference value of the d-axis stator current for which the input power is minimum. The input power is calculated from the measured dc-bus current and dc-bus voltage of the inverter. A rotor-oriented vector control of the synchronous reluctance machine with the optimization efficiency controller is achieved with a DSP board (TMS302C31). Experimental results are presented to validate the proposed control methods. It is shown that stability problems can appear during the search process.
\end{abstract}

Keywords: Efficiency optimization, Fibonacci search method, search controller, synchronous reluctance motor.

\section{Introduction}

In the field of servo-drive applications, the Synchronous Reluctance Motors (SynRM) represents an alternative to other types of AC motors, such as induction motor or permanent magnet synchronous one [1], [2]. The SynRM presents a simple, robust and cheaper rotor structure and has simpler field oriented control compared to that of induction motor drives. The absence of magnets allows controlling the machine in the field-weakening region (constant power operation) and makes the torque insensitive to temperature variations. The main drawback of SynRM is the presence of torque ripples which cause undesirable acoustic noise and vibrations.

The SynRM has recently attracted the efforts of a number of researchers. The last developments concern three different topics. The first one is the design improvement of the rotor structure to maximize the saliency ratio $L d / L q$ and improve the electromagnetic torque [3]-[5]. The second one concerns the development of theoretical models which take into account magnetic saturation (crossed-magnetization) and space

Corresponding author: T. Lubin e-mail: thierry.lubin@ green.uhp-nancy.fr.

Tel.: +33(0)383684127

Fax: +33(0)383684133 harmonics effects [6]-[8]. The last topic concerns the development of control strategies to improve both dynamic and steady state performances like the maximum torque per ampere control (MTA) [9]-[11] or the maximum efficiency control [16], [18].

The efficiency of a variable frequency drive can be improved by the flux control [12]. The flux level (usually control by the stator d-axis current $I s d$ ) is adjusted by the optimum-efficiency controller in relation to the load torque and to the rotor speed of the machine. The rated flux is imposed for the nominal operating condition and is decreased at light loads or at non rated speeds. A number of methods for efficiency improvement have been proposed in the literature for induction motors and synchronous reluctance motors. In general, two major approaches can be identified.

The first one is based on a loss model of the motor (copper and iron losses) and is called Loss Model Controller (LMC) [12]-[16]. The method consists of computing the losses and selecting the flux level that minimizes these losses. This approach requires a good knowledge of the motor parameters, including the influence of variable frequency and flux level on the core losses and the effect of magnetic saturation on the inductance values. 


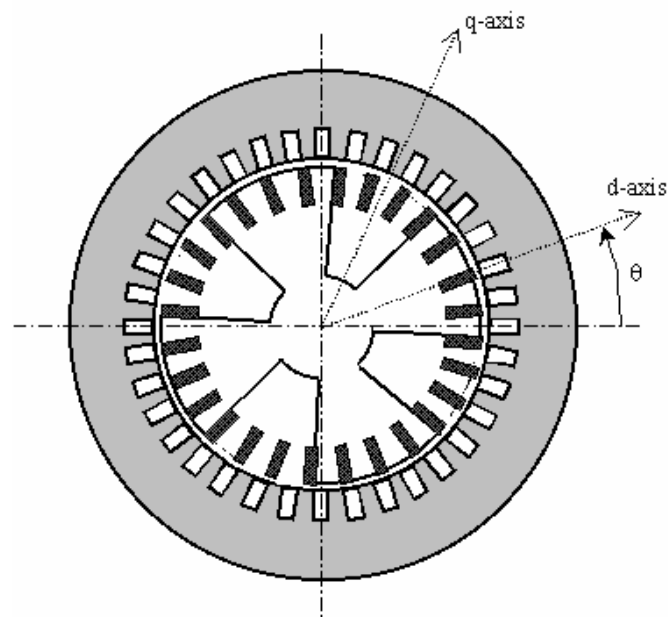

Fig. 1. Cross section of the studied machine.

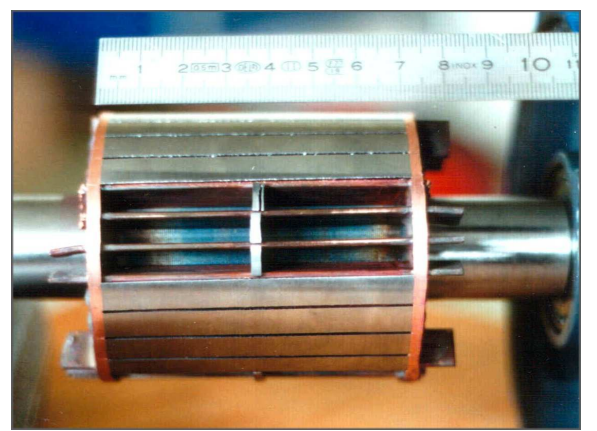

Fig. 2. Rotor structure of the studied machine.

The second approach uses a search algorithm and is called SC method (Search Controller) [17]-[21]. The electrical input power is measured and is minimized by different algorithms. The implementation of a search controller is simpler and does not require the knowledge of the motor loss model. It can be universally applied to AC machines. The main drawback of this method is the need of additional sensors to measure the input power and its relatively low speed due to the search process compare to the LMC method. Matsuo et al. [18] proposed a solution of minimizing the input power of a SynRM drive by adding a small amount of perturbation to the flux current reference Isd. However, the variation of $I s d$ during the search process and around its optimal value in steady state results in undesirable torque disturbance. Moreover, the developed method is slow reaching the optimum. Kim et al.[19], Sousa et al. [20] and Ta and Hori [21] used respectively Fibonacci search method, fuzzy-logic based controller and the Golden section search method to minimize the input power of an induction motor drive. These methods improve the speed convergence of the search process $(\mathrm{t}<2 \mathrm{~s})$. The torque pulsation caused by the stepwise decrease in the flux current has been simply eliminated by incorporating a low-pass filter in the efficiency optimization algorithm. These methods using Fibonacci or Golden section algorithms to minimize the input power have not yet been used for SynRM.

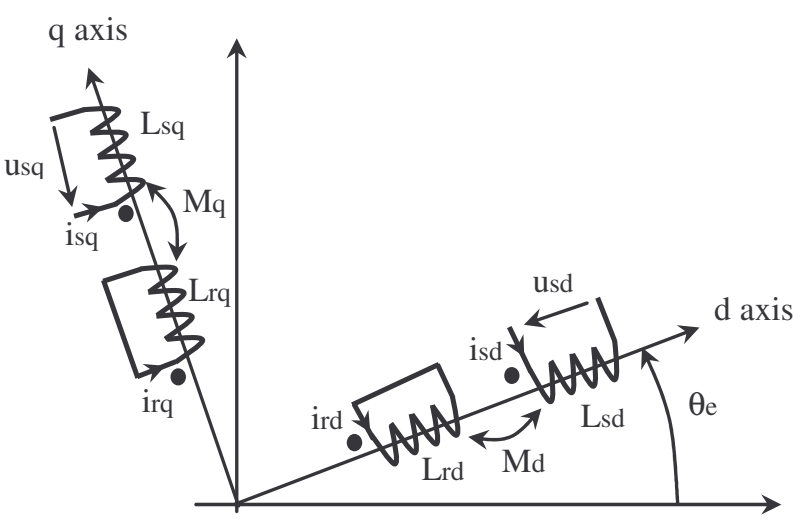

Fig. 3. Two-axis model in the rotor reference frame.

This paper presents an optimal efficiency method for vector-controlled synchronous reluctance motor drive. The loss minimization control is implemented with a search controller using the Fibonacci's search algorithm as proposed in [19]. The studied machine is a classical low power line start synchronous reluctance machine $(600 \mathrm{~W})$ with a rugged rotor and a complete squirrel cage. The stator is the same as an induction motor and has symmetrical three phase windings. The cross section of the experimental machine is shown in Fig. 1. Photography of the rotor is given in Fig. 2.

The contents of this paper are organized as follows. In section 2, the basic equations and the rotor-oriented vector control of the SynRM are developed. Experimental results of input power measurement are given for transient and steady state conditions for different load torque and speed values. The implementation of the optimal efficiency control using Fibonacci search algorithm is developed in section 3 . Comparisons between simulation results and experimental tests are given and show the validity and the limits of the proposed method. Section 4 concludes the paper.

\section{Vector control of SynRM and input power measurement}

\section{A. Basic equations}

The two-axis representation of the synchronous reluctance motor is given in Fig. 3. For the modeling, magnetic hysteresis, skin effect (in the rotor bars) and iron losses are neglected. The air-gap magnetomotive forces are assumed to be sinusoidally distributed.

The well-known $d$-q voltage equations in the rotor reference frame are as follows:

$$
\begin{aligned}
& \text { usd }=\text { Rs.isd }+\frac{d \Psi_{s d}}{d t}-\omega e . \Psi_{s q} \\
& \text { usq }=\text { Rs.isq }+\frac{d \Psi_{s q}}{d t}+\omega_{e} . \Psi_{s d}
\end{aligned}
$$




$$
\begin{aligned}
& 0=\operatorname{Rrd} \cdot \operatorname{ird}+\frac{\mathrm{d} \Psi \mathrm{rd}}{\mathrm{dt}} \\
& 0=\operatorname{Rrq} \cdot \operatorname{irq}+\frac{\mathrm{d} \Psi \mathrm{rq}}{\mathrm{dt}}
\end{aligned}
$$

The stator and rotor flux linkages that appear in (1)-(4) are related to the currents by:

$$
\begin{aligned}
& \Psi_{\mathrm{sd}}=\mathrm{Lsd} \cdot \mathrm{i}_{\mathrm{sd}}+\mathrm{Md} \cdot \mathrm{ird} \\
& \Psi_{\mathrm{sq}}=\mathrm{Lsq} \cdot \mathrm{isq}_{\mathrm{sq}}+\mathrm{Mq} \cdot \mathrm{irq}_{\mathrm{rq}} \\
& \Psi_{\text {rd }}=\mathrm{Lrd} \cdot \text { ird }+ \text { Md } \cdot \text { isd } \\
& \Psi_{\mathrm{rq}}=\mathrm{Lrq} \cdot \text { irq }+\mathrm{Mq} \cdot \text { isq }
\end{aligned}
$$

All the electrical parameters of the SynRM used for tests are listed in the appendix. The equation of motion and the expression of the electromechanical torque are written as:

$\mathrm{J} \cdot \frac{\mathrm{d} \Omega}{\mathrm{dt}}+\mathrm{f} \cdot \Omega=\mathrm{Tem}-\mathrm{T}$

$\mathrm{Tem}=\mathrm{p} .\left(\Psi_{\mathrm{sd}} . \mathrm{isq}_{\mathrm{sq}}-\Psi_{\mathrm{sq}} . \mathrm{isd}_{\mathrm{sd}}\right)$

where $\mathrm{J}$ is the moment of inertia, $\mathrm{f}$ the friction coefficient and $\mathrm{T}$ the load torque.

The instantaneous input power is expressed in terms of the direct and quadrature-axis stator voltages and currents components as:

$$
\mathrm{P}=\mathrm{usd} \cdot \text { isd }+\mathrm{usq} \cdot \text { isq }
$$

\section{B. Vector control of SynRM}

A functional block diagram of the synchronous reluctance machine vector control is given in Fig. 4. The SynRM is fed by a voltage-source PWM inverter with a switching frequency of $10 \mathrm{kHz}$. The control is achieved with a DSP board (TMS320C31).

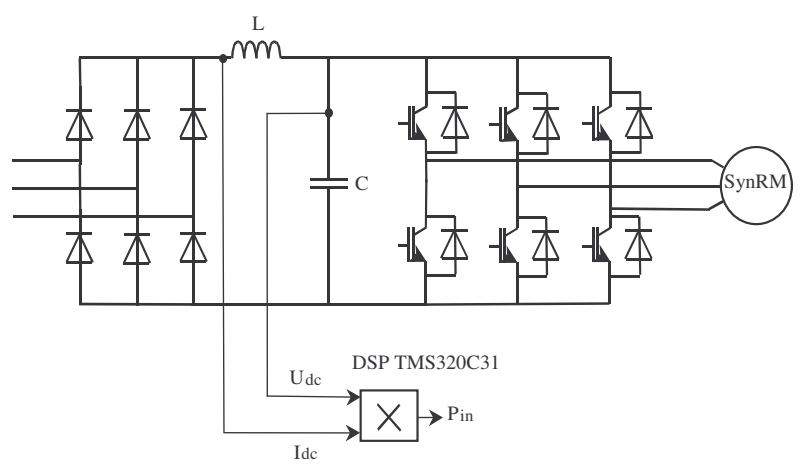

Fig. 5. Input power measurement.

Hall effect current transducers and a rotor position sensor with a resolution of 1024 pulses/revolution provide the information to monitor the current vector $I_{s} d$ and $I_{s q}$ from the phase currents $i s a$ and $i s b$. Currents are sampled every $0.1 \mathrm{~ms}$. Conventional PI controllers are used for current loops (d-axis and q-axis current controllers). The PI controllers allow to obtain a response time of $3 \mathrm{~ms}$ in both $\mathrm{d}$-axis and $\mathrm{q}$-axis current loops.

For the speed loop, an IP controller with an integrator antiwindup is used. IP algorithm is executed every $1 \mathrm{~ms}$ and generate the needed Isqref current reference. A current limiter is used to ensure that stator current remains within rated value.

The synchronous reluctance machine is coupled with a DC generator. For a constant output speed (maintained by the speed loop), the load torque $\mathrm{T}$ is maintained constant with a fixed load resistor on the DC generator and a fixed field excitation.

The efficiency-optimization block using Fibonacci search controller is represented in Fig. 4. It searches the optimal reference value of the flux component of the stator current Isdref for which the input power Pin is minimum. The speed error $\Delta \mathrm{N}$ is used to restore the rated value of the flux current after a change in speed reference value or a change in load torque to ensure good dynamic transient [19], [20].

The on-line efficiency optimization control will be developed in section 3 .

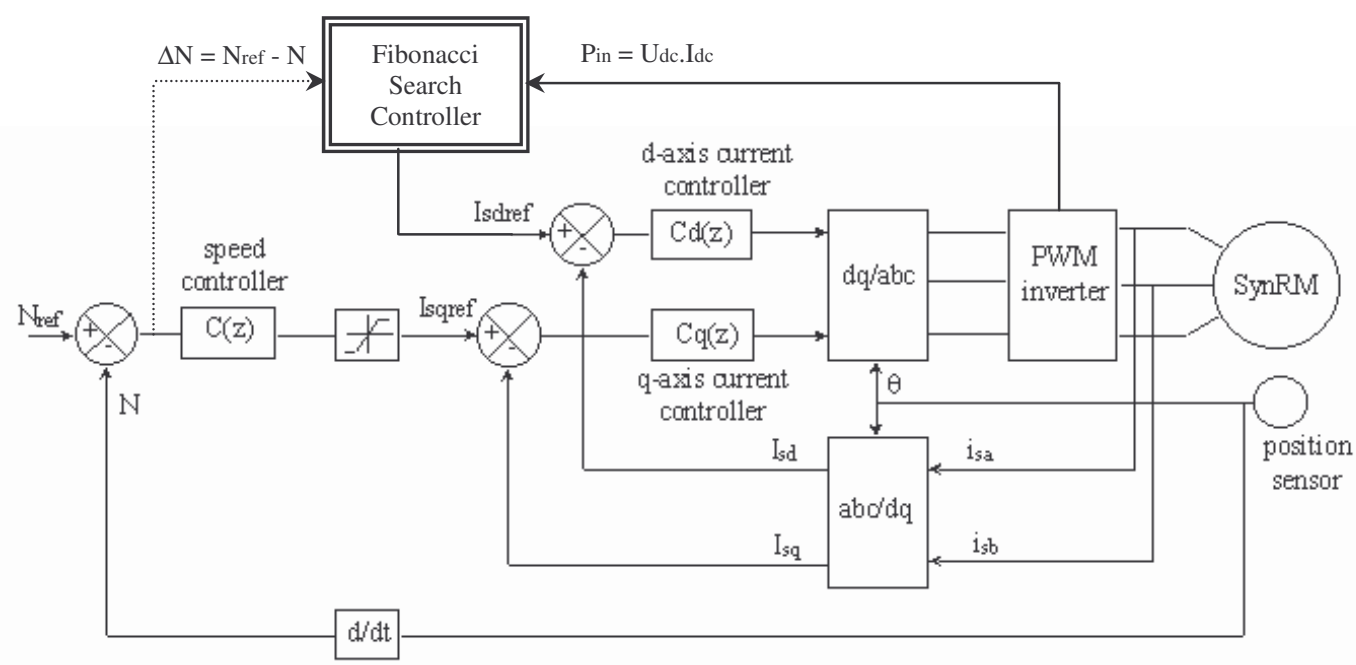

Fig. 4. Block diagram of the experimental system. 


\section{Input power measurement}

As shown in Fig. 5, the input power is calculated as the product of the measured dc-bus voltage Udc by the dc-bus current Idc:

Pin $=$ Udc.Idc

The input power Pin includes motor output power, motor losses and inverter losses. The input power measurement must be noiseless to ensure a good working of the search controller [14]. So, the dc-link current Idc is first filtered with selfinductance $\mathrm{L}=20 \mathrm{mH}$ as shown in Fig. 5. The input power is then calculated with a $1 \mathrm{~ms}$ sampling period (the same as the speed loop) and is averaged over 20 periods in order to reduce the noise.

An experimental study of the input power behavior of the synchronous reluctance motor drive was carried out with the implemented experimental drive system. Fig. 6 shows the experimental result of the input power measurement during transient conditions. Figures 6(a) to 6(d) show respectively the $\mathrm{d}$-axis current (Isd), the q-axis current (Isq), the mechanical speed $(\mathrm{N})$, and the power input (Pin). For this test, the machine is first initialized with the rated value of the flux current (Isdref $=2.5 \mathrm{~A}$ ). The machine is then accelerated from 0 to $400 \mathrm{rpm}$ under no-load condition. It can be seen in Fig 6(b) that q-axis current is limited at Isqrefmax $=7 \mathrm{~A}$ to ensure that stator current remains within rated value. A load torque step of $3 \mathrm{Nm}$ is applied at $\mathrm{t}=2.2 \mathrm{~s}$.

Fig. 6(d) shows the input power behavior during the test. It can be seen that the input power attains about $900 \mathrm{~W}$ during the speed acceleration. It reaches the value of almost $150 \mathrm{~W}$ in steady state for no load condition. When the load torque is applied, the q-axis current increases from about $0.8 \mathrm{~A}$ to $4 \mathrm{~A}$. It can be seen in Fig. 6(d) that the input power increases from $150 \mathrm{~W}$ to $400 \mathrm{~W}$ after a transient of about $0.5 \mathrm{~s}$.

This test shows that the input power can be measured with precision (the noise is low) during transient and steady state conditions. The input power measurement will be used in the next section with the optimum efficiency controller.

Fig. 7 illustrates the variations of the measured input power Pin versus d-axis current in steady state condition for different values of the mechanical speed $(250,500$ and $800 \mathrm{rpm})$ and different values of the load torque $\mathrm{T}(0,1.2,2$ and $3 \mathrm{Nm})$. To obtain these curves, the output power is maintained constant with the DC generator and the d-axis current reference Isdref is varied (the search controller is inhibited during these tests). Then, the corresponding input power is measured by using (11).

Fig. 7 indicates that there exists a minimum input power operating point for all the combinations of speed and load torque values. It can be observed that the optimal value of the $\mathrm{d}$-axis current increases with the loading and is not subject to the speed value. For the studied machine, the optimal value of the flux current is always included between a lower value of about $0.5 \mathrm{~A}$ and a higher value of about $3 \mathrm{~A}$. One can also see that the input power is flat near the point of optimal efficiency. Therefore, the power measurement must be very precise and noiseless to be used with the search controller.

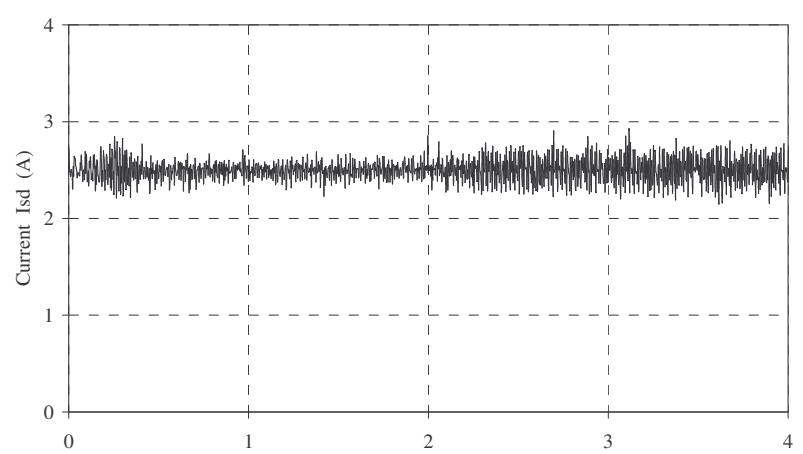

(a)

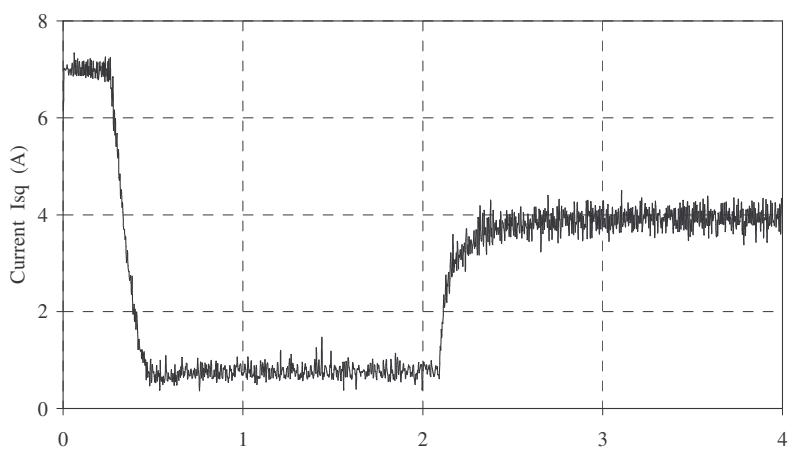

(b)

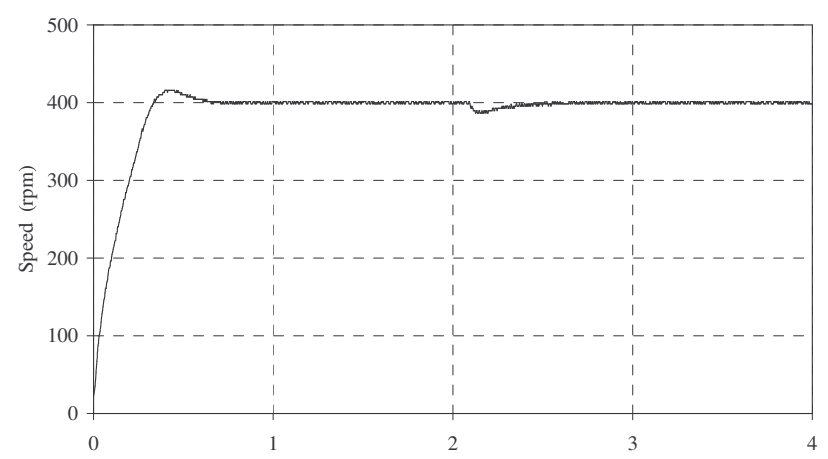

(c)

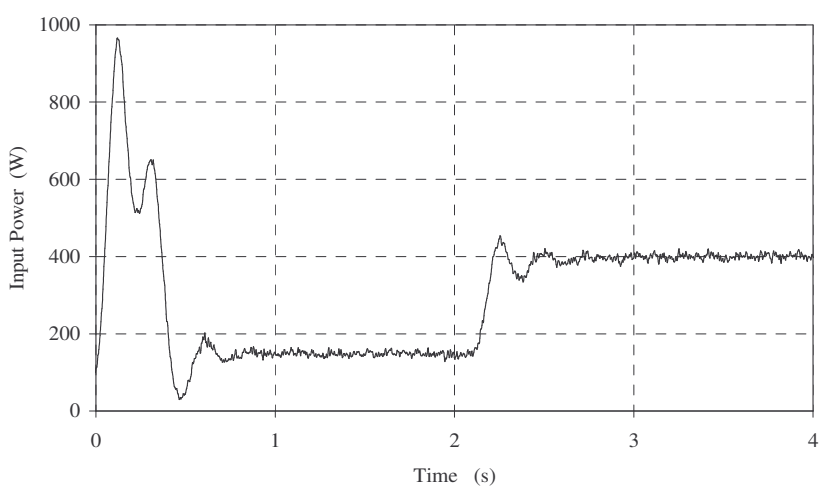

(d)

Fig. 6. Starting transient and load torque step transient for SynRM under test: (a) d-axis current Isd, (b) q-axis current Isq, (c) mechanical speed N, (d) input power Pin. Experimental results 

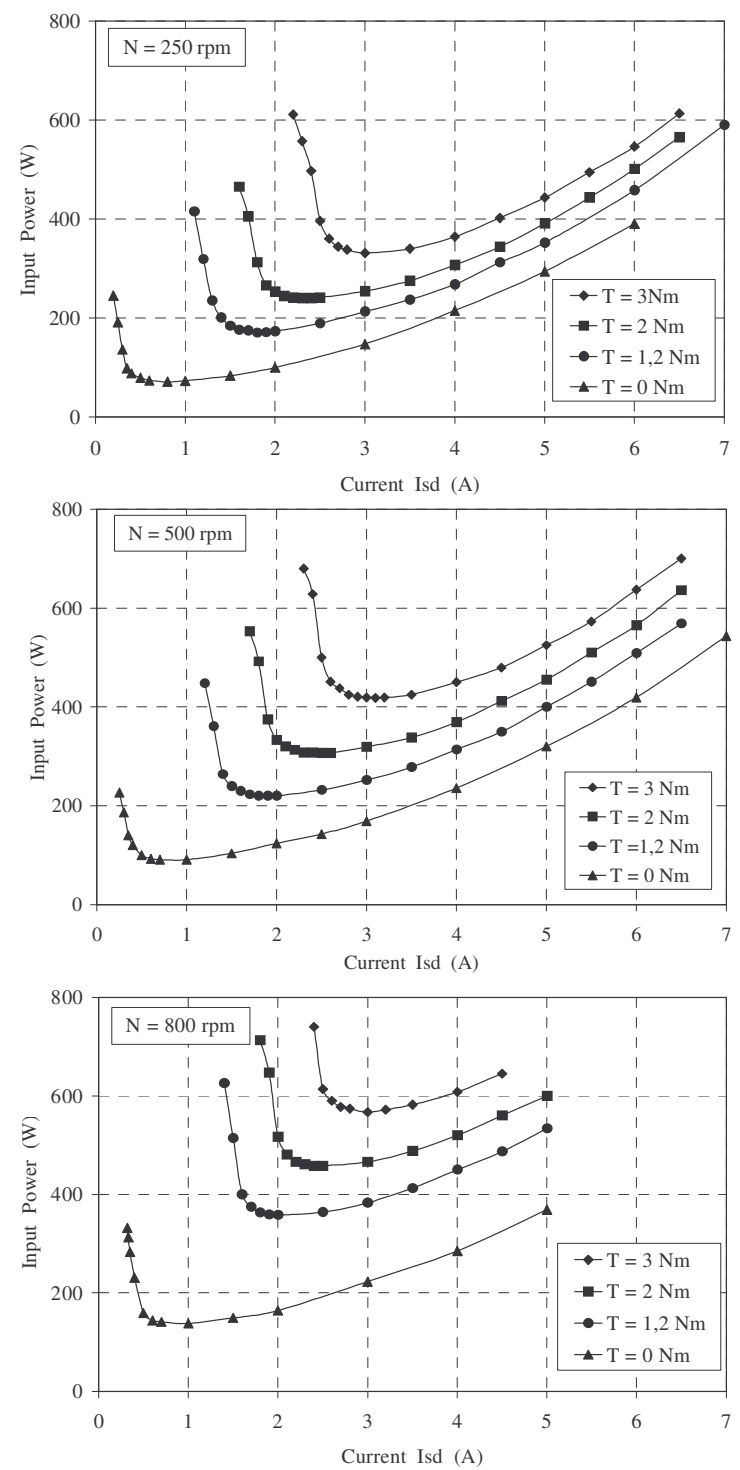

Fig. 7. Input power versus d-axis current for different values of speed and load torque. Experimental results

\section{Optimum efficiency controller}

\section{A. Fibonacci Search Method}

The efficiency controller searches the optimal value of the $d$-axis component of stator current, for which the input power of the drive is minimum. The efficiency control is based on the Fibonacci search algorithm. The Fibonacci search method is known as the most efficient (golden section is next) that it requires the smallest number of input power evaluations to find the optimum value of the $d$-axis current [22]. This method is applicable to unimodal functions with a single variable (a function is unimodal when it presents a unique optimum in a given interval). It not requires the calculation of derivatives at each step (it is important when the signal presents noise).

The Fibonacci search is based on the sequence of Fibonacci numbers which are defined by the equations:

$$
\begin{aligned}
& F_{0}=F_{1}=1 \\
& F_{k}=F_{k}-1+F_{k}-2 \quad \forall k \geq 2 \\
& \left\{F_{k}\right\}=\{1,1,2,3,5,8,13,21,34,55,89 \ldots \ldots \ldots \ldots\}
\end{aligned}
$$

The principle of Fibonacci search algorithm applied to input power minimization is described in Fig. 8. This figure shows the search process for 4 input power evaluations $\mathrm{P}_{1}, \mathrm{P}_{2}, \mathrm{P}_{3}$ and $\mathrm{P} 4$. At the beginning, we start the algorithm by defining the initial conditions. The initial conditions are the minimum and maximum values of the $\mathrm{d}$-axis current Isdmin and Isdmax. These values determine the length of the first search interval L1. We must also define the flux current tolerance $\lambda$ around its optimal value to predetermine the number of the input power evaluations $n$ [22]. The number of input power evaluations is the integer $n$ such that:

$\mathrm{F}_{\mathrm{n}+1} \leq \frac{\mathrm{Isd} \max -\mathrm{Isd} \min }{\lambda} \leq \mathrm{F}_{\mathrm{n}+2}$

The algorithm can now calculate the values of $d$-axis current references Isd1 and Isd2 in the first interval L1 (L2 is the length of the second interval):

$$
\begin{aligned}
& \mathrm{L}_{2}=\frac{\mathrm{F}_{\mathrm{n}-1}}{\mathrm{~F}_{\mathrm{n}}} \cdot(\mathrm{Isd} \max -\mathrm{Isd} \min )+\frac{(-1)^{\mathrm{n}}}{\mathrm{Fn}_{\mathrm{n}}} \cdot \lambda \\
& \mathrm{Isd} 1=\mathrm{Isd} \max -\mathrm{L} 2 \\
& \mathrm{Isd} 2=\mathrm{Isd} \min +\mathrm{L} 2
\end{aligned}
$$

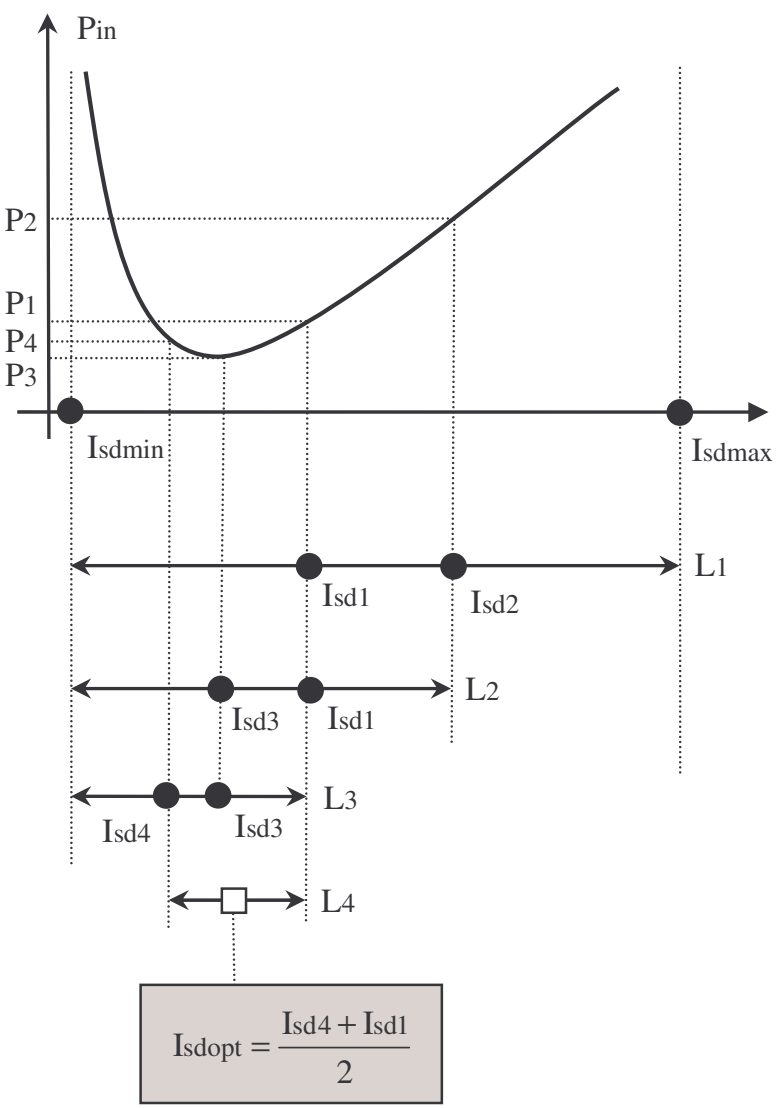

Fig. 8. Decision process for the Fibonacci search algorithm. 
The input powers $\mathrm{P} 1$ and $\mathrm{P} 2$ corresponding to Isd1 and Isd2 are measured according to (11) and are compared. For the studied example, the input power $\mathrm{P} 1$ is less than the input power $\mathrm{P} 2$ and the new search interval becomes L2. Although two input power measures are required in the initial interval $\mathrm{L} 1$, only one further input power measure $\left(\mathrm{P}_{3}\right)$ is required in the reduced interval L2. The input powers $\mathrm{P}_{3}$ and $\mathrm{P} 1$ are compared and the interval is reduced to L3. The search procedure continues until the number of iteration $n$ defined by (13) is attained. The optimal value of the reference $d$-axis current is placed to the middle of the last interval. Fig. 9 shows the flowchart of minimization of the input power using Fibonacci search algorithm.
Several tests have been carried out and compared with simulation results to confirm the validity of the algorithm. We are going to present the results of three tests. The first one is a no load test with a constant speed reference of $500 \mathrm{rpm}$. The second one is a $2 \mathrm{Nm}$ load torque test with constant speed reference of $500 \mathrm{rpm}$. The last test is a rated load torque test with a constant speed reference of $500 \mathrm{rpm}$. This last test allows to show that stability problems can appear during the search process if the lower value of the first search interval Isdmin is chosen too small.

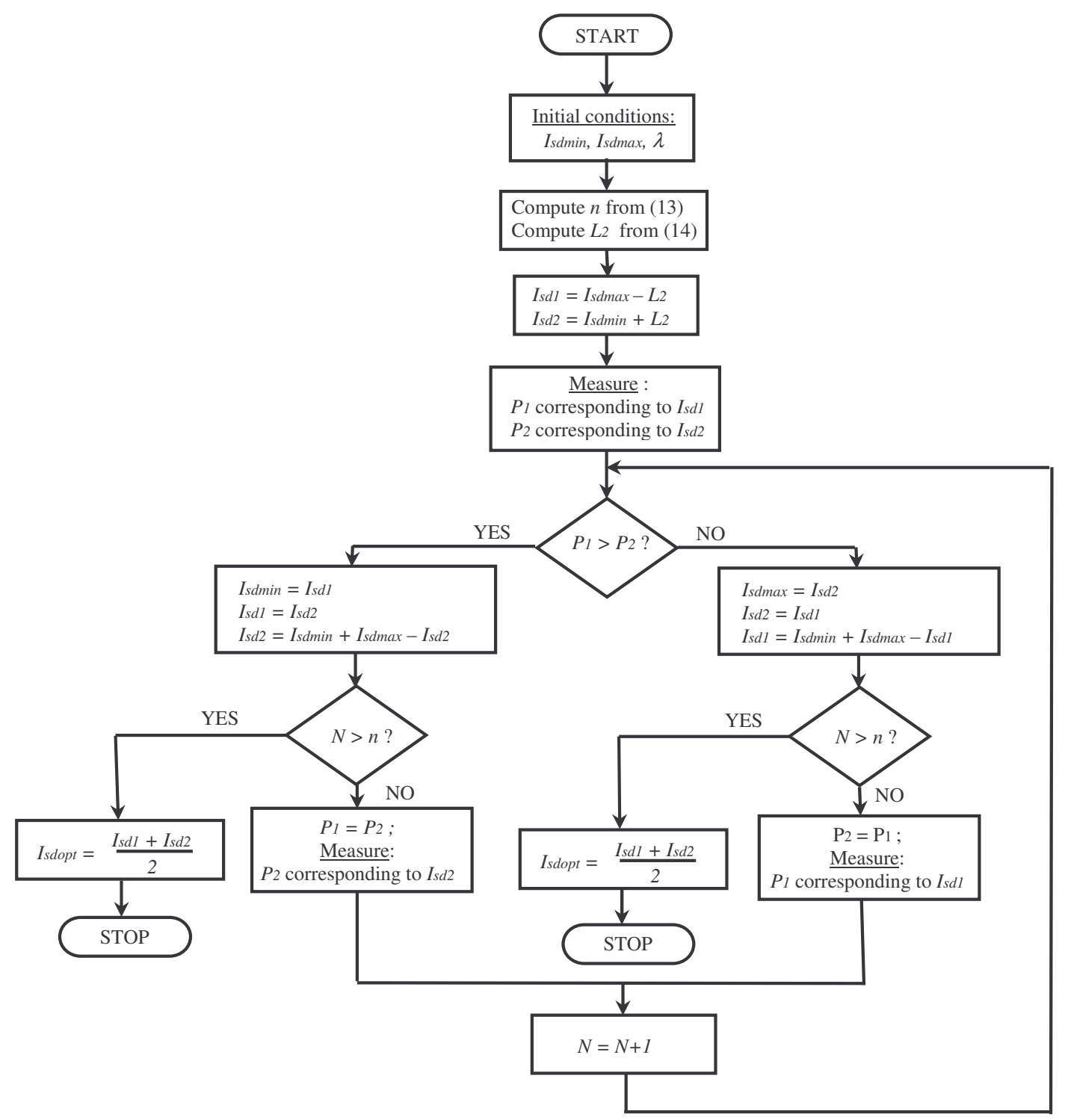

Fig. 9. Flowchart of minimization of the input power using Fibonacci search algorithm. 


\section{B. No-load Test With Constant Speed Reference}

Fig. 10 shows simulation results for no-load condition. The rotor speed is fixed at $500 \mathrm{rpm}$. The simulation algorithm is based on the SynRM model developed in section II. The inverter is considered as an ideal PWM power supply. The simulation algorithm is written in C-language and uses a standard fourth order Runge-Kutta integration routine.

Initial conditions for Fibonacci search algorithm (length of the first interval <Isdmin; Isdmax > and d-axis current tolerance $\lambda$ ) are fixed using experimental results of Fig. 7:

Isd $\min =0 \mathrm{~A} \quad \mathrm{Isd} \max =5 \mathrm{~A} \quad \lambda=0.2 \mathrm{~A}$

The number of input power evaluations $n$ and the $d$-axis current references Isd1 and Isd2 are calculated by using (13) and (14):

$\mathrm{n}=6 \quad \mathrm{Isd} 1=1.9 \mathrm{~A} \quad \mathrm{Isd} 2=3.1 \mathrm{~A}$

The time period of one step change of $d$-axis current reference is fixed to $1 \mathrm{~s}$. This value is determined by the transient behavior of the input power (Fig. 6). The input power must be measured after the steady state is established.

Fig. 10(a) and Fig. 10(b) show respectively the d-axis current Isd and the input power P. The input power is calculated with (11). The $d$-axis current is initialized with its rated value $($ Isdref $=2.5 \mathrm{~A})$. At $\mathrm{t}=5 \mathrm{~s}$, the efficiency optimization is activated.

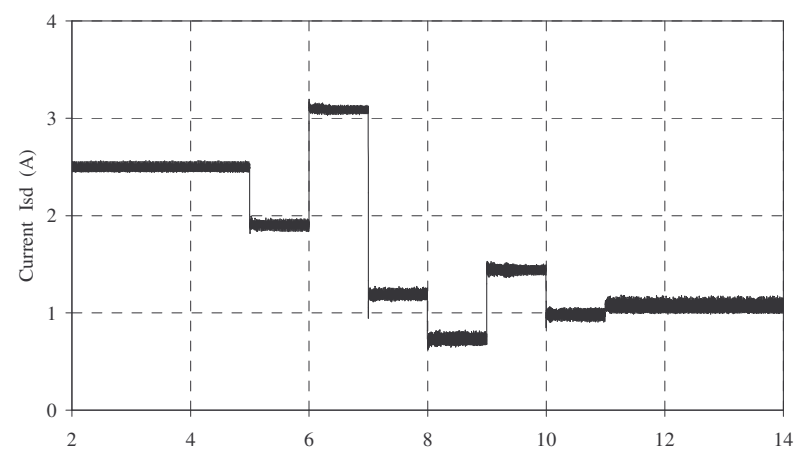

(a)

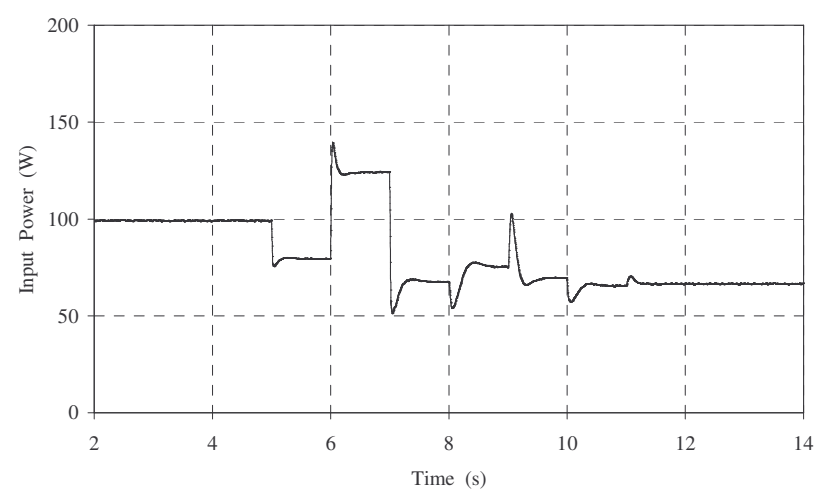

(b)

Fig. 10. Simulation results for no-load torque and with a speed reference of 500 rpm: (a) d-axis current Isd, (b) input power P.
After six step changes in $d$-axis current reference, the input power is reduced from $100 \mathrm{~W}$ to about $65 \mathrm{~W}$. A reduction of $35 \%$ power input is obtained. The optimal value of $d$-axis current reference after the search process is equal to $1 \mathrm{~A}$.

Fig. 11 shows experimental results obtained for identical conditions as reported in the previous simulation. The results are in close agreement to the simulation ones. The input power decreases from $150 \mathrm{~W}$ to $100 \mathrm{~W}$. The $d$-axis current decreases from $2.5 \mathrm{~A}$ to $0.8 \mathrm{~A}$ which is the optimal value for no load condition and a mechanical speed of $500 \mathrm{rpm}$ as shown in Fig. 7. One can observed that the simulated input power are smaller than the experimental one because inverter losses, iron losses and stray losses has not been taken into account for the simulation. Fig. 11(c) shows that the mechanical speed is not disturbed during the search process.

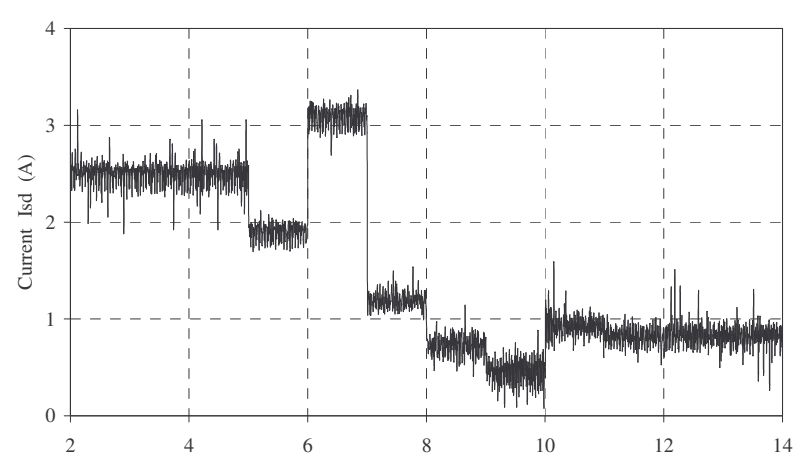

(a)

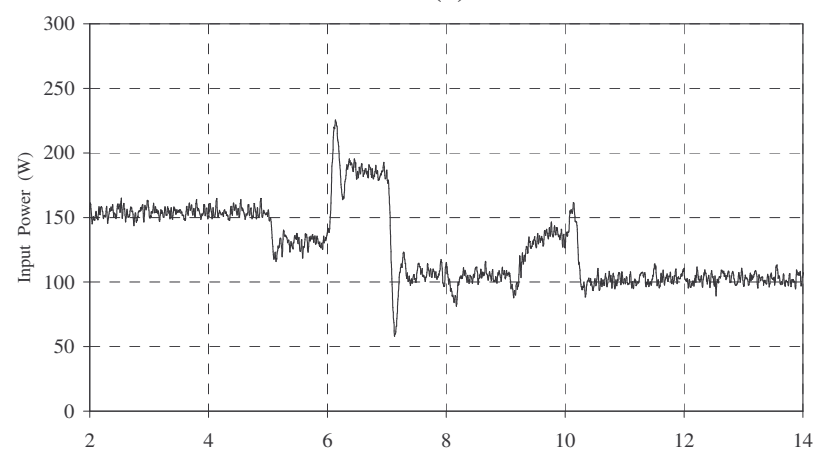

(b)

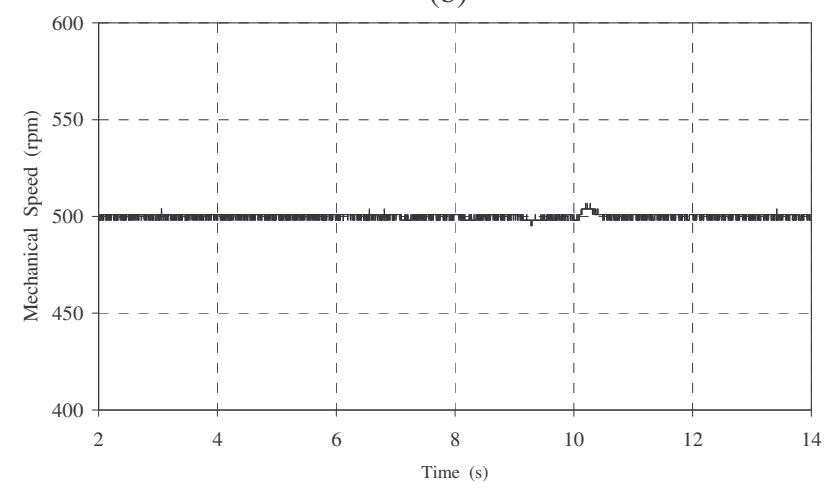

(c)

Fig. 11. Experimental results for no-load torque and with a speed reference of $500 \mathrm{rpm}$ : (a) d-axis current Isd, (b) input power Pin, (c) mechanical speed N. 


\section{Load Test With Constant Speed Reference}

Fig. 12 shows experimental results obtained for a load torque of $2 \mathrm{Nm}$ (0.66 p.u.) and a speed value of $500 \mathrm{rpm}$. Regulating of the Fibonacci search algorithm are the same that previously (16). The initial value of Isdref is deliberately chosen large (Isdref $=6 \mathrm{~A}$ ) to show the accuracy of the optimization efficiency search process. At $\mathrm{t}=5 \mathrm{~s}$, the efficiency optimization is activated. The input power is reduced from $560 \mathrm{~W}$ to $320 \mathrm{~W}$. The $d$-axis current decreases from $6 \mathrm{~A}$ to $2.2 \mathrm{~A}$ which is the optimal value for the test conditions (500 rpm, $2 \mathrm{Nm}$ ) as shown in Fig. 7.

D. Stability problem; lower limit for Isdmin

During the search process, the d-axis current reference may be so small that the motor pulls out because the electromagnetic torque becomes smaller than the load torque.

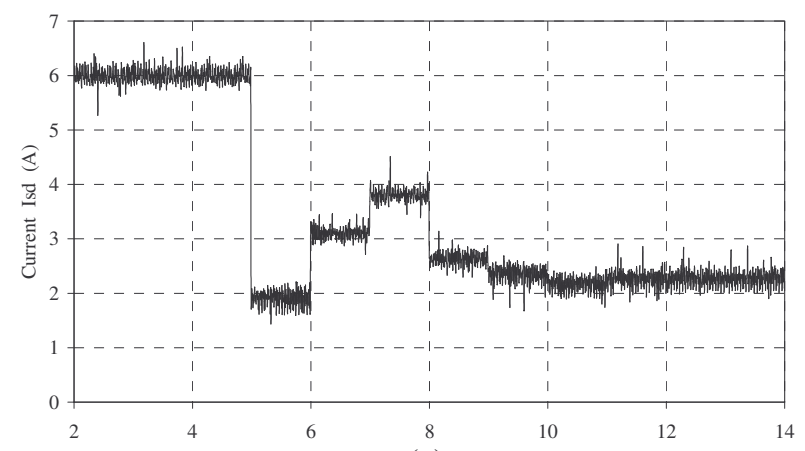

(a)

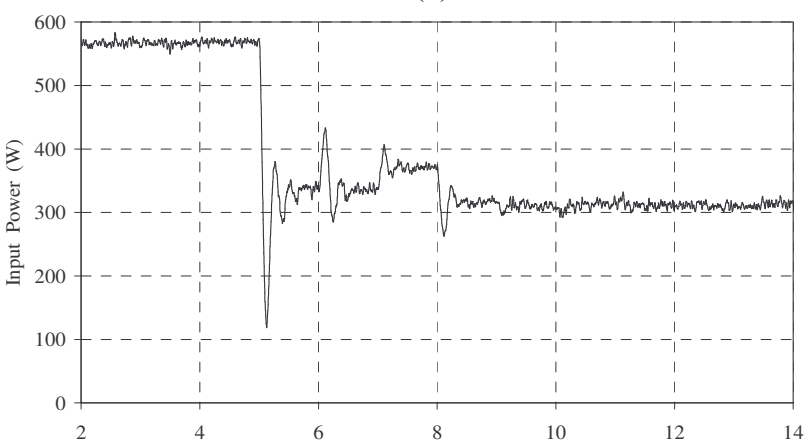

(b)

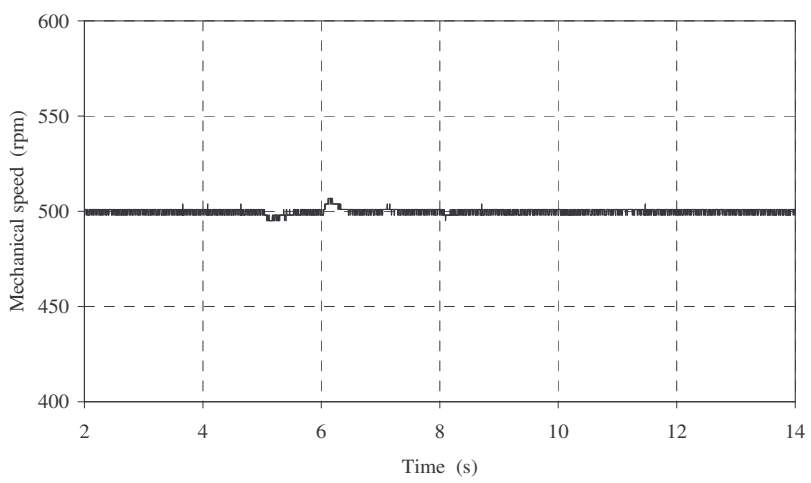

(c)

Fig. 12. Experimental results for $2 \mathrm{Nm}$ load torque and $\mathrm{Nref}=500 \mathrm{rpm}$, (a) d-axis current Isd, (b) input power Pin, (c) mechanical speed N.

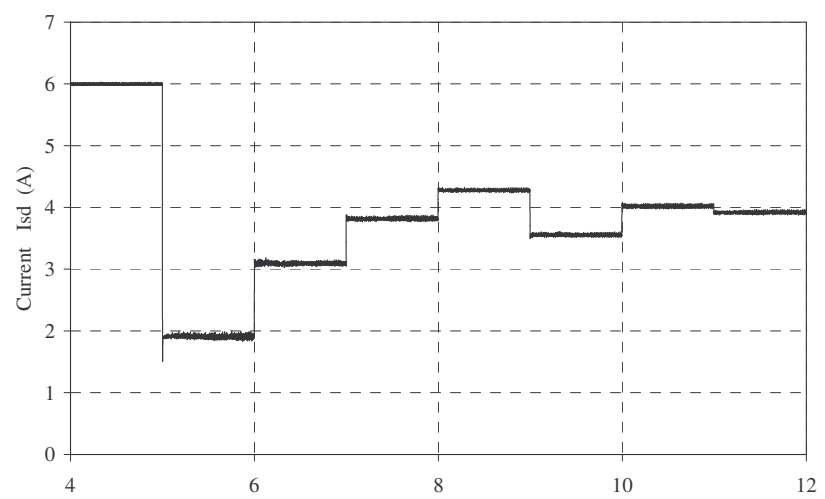

(a)

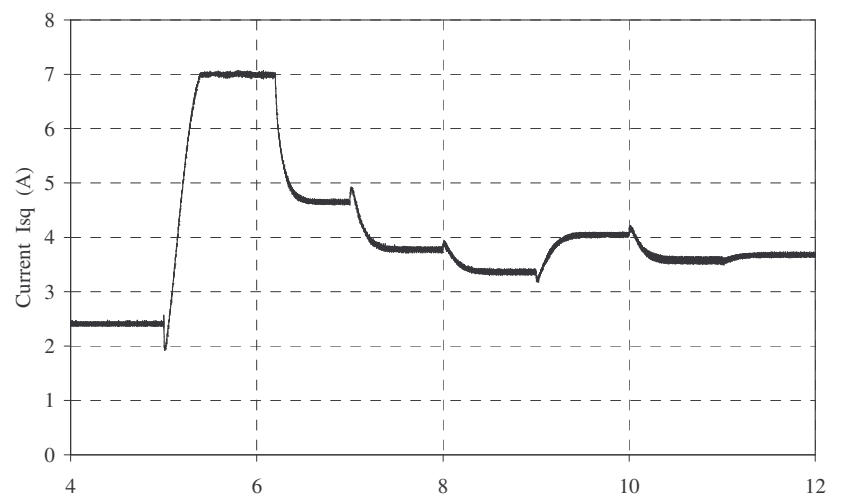

(b)

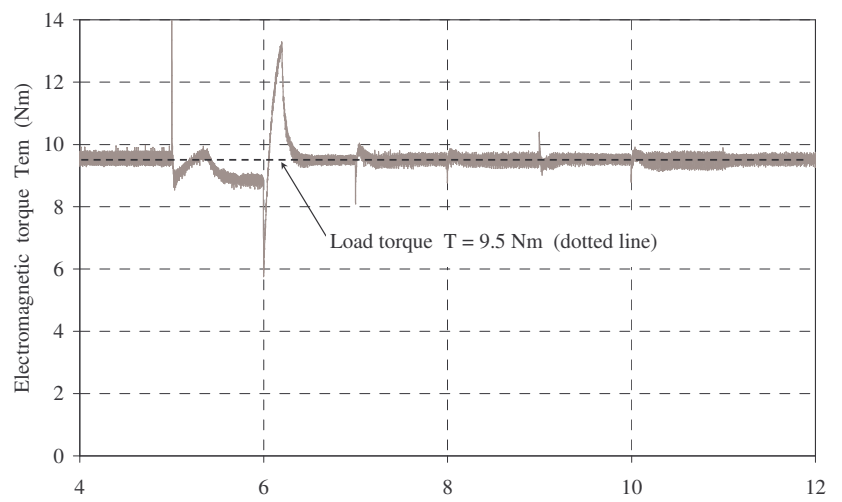

(c)

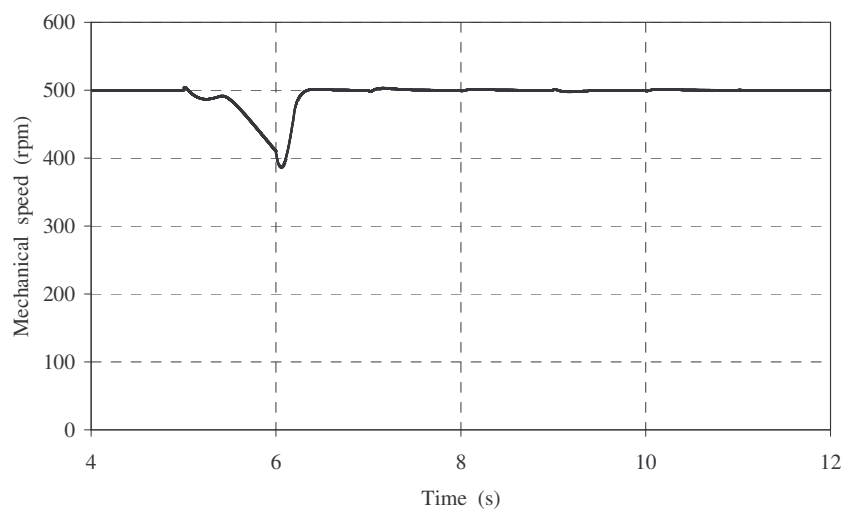

(d)

Fig. 13. Stability problem; Simulation results for $9.5 \mathrm{Nm}$ load torque and $\mathrm{Nref}$ = $500 \mathrm{rpm}$ : (a) d-axis current Isd, (b) q-axis current Isq, (c) electromagnetic torque Tem, (d) mechanical speed $\mathrm{N}$. 
Fig. 13 shows simulation results where stability problem occurs during the first step of the search process $(5 \mathrm{~s}<\mathrm{t}<6 \mathrm{~s})$. The rotor speed is fixed at $500 \mathrm{rpm}$ and the load torque is fixed at a large value of $9.5 \mathrm{Nm}$. During the first step of the search process, the d-axis current reference is fixed at Isd $1=$ 1.9 A (16) and the q-axis current reaches its limit (isq = $7 \mathrm{~A}$, see Fig. 13(b)). In steady state condition, the electromagnetic torque of synchronous reluctance motors depends of the two components of the stator current vector isd and isq :

Tem $=p \cdot($ Lsd - Lsq $) \cdot$ isd $\cdot$ isq

The electromagnetic torque value corresponding to isd $=1.9 \mathrm{~A}$ and isq $=7 \mathrm{~A}$ is equal to $8.8 \mathrm{Nm}$ (the unsaturated values of Lsd and Lsq are given in the appendix). During the first step of the search process, the electromagnetic torque value is smaller than the load torque value as it can be seen in Fig. 13(c). Therefore, the machine pulls out and the mechanical speed decreases strongly.

Fig. 14 shows experimental results obtained for rated load torque and a mechanical speed fixed at $500 \mathrm{rpm}$. For this test, the Fibonacci algorithm is adjusted as previously (16). Fig. 14(a) and Fig. 14(b) show respectively the $d$-axis current and the $q$-axis current. At the first step of the search process, the $q$ axis current reaches its limit and the speed decreases strongly as foreseen by the simulation results. To avoid such problem, one must impose a minimum limit for Isdmin (14). Several experimental results have shown that this lower limit should be the optimal value of $d$-axis current for no-load condition $($ Isdmin $=0.8 \mathrm{~A})$.

\section{Conclusion}

From the energy-saving viewpoint, it is important to improve the efficiency of variable speed motor drives in the process industries. In this paper, input power minimization of a synchronous reluctance motor drive with Fibonacci search controller has been presented. Experimental results obtained for different levels of load torque have shown the accuracy of the proposed method. However, We have shown that the lower limit of the first search interval (Isdmin) had to be chosen with care to avoid stability problem during the search process.

\section{Appendix}

Nomenclature:

$\begin{array}{ll}\text { usd, usq: } & \text { d- and q-axis stator voltages, } \\ \text { isd, isq: } & \text { d- and q-axis stator currents, } \\ \text { ird, irq: } & \text { d- and q-axis damper currents, } \\ \Psi_{\text {sd, } \Psi_{\text {sq: }}} & \text { d- and q-axis total stator flux linkages, } \\ \Psi_{\text {rd, }} \Psi_{\text {rq: }} & \text { d- and q-axis total rotor flux linkages, } \\ \text { Rs: } & \text { stator resistance, } \\ \text { Rrd, Rrq: } & \text { d- and q-axis damper resistances, } \\ \text { Lsd, Lsq: } & \text { d- and q-axis stator inductances, } \\ \text { Lrd, Lrq: } & \text { d- and q-axis rotor inductances, } \\ \text { Md, Mq: } & \text { d- and q-axis mutual inductances, } \\ \text { J: } & \text { moment of inertia, }\end{array}$

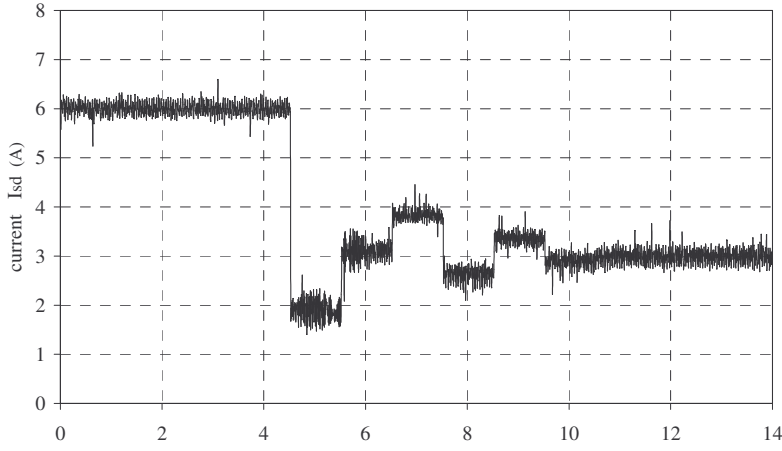

(a)

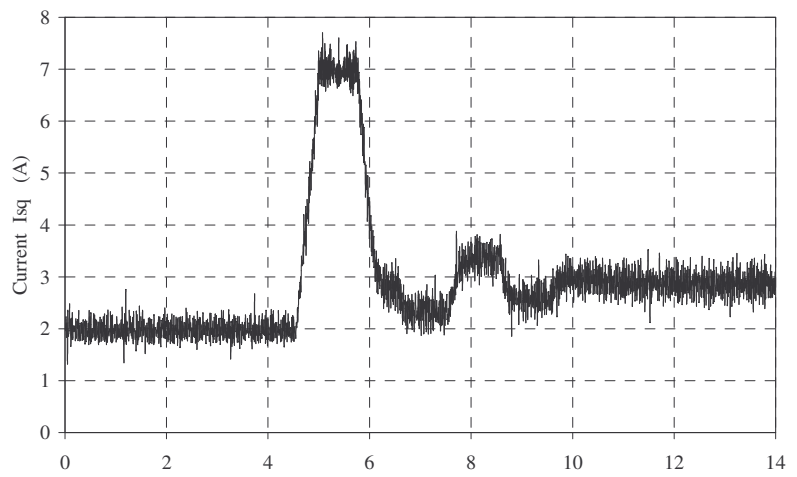

(b)

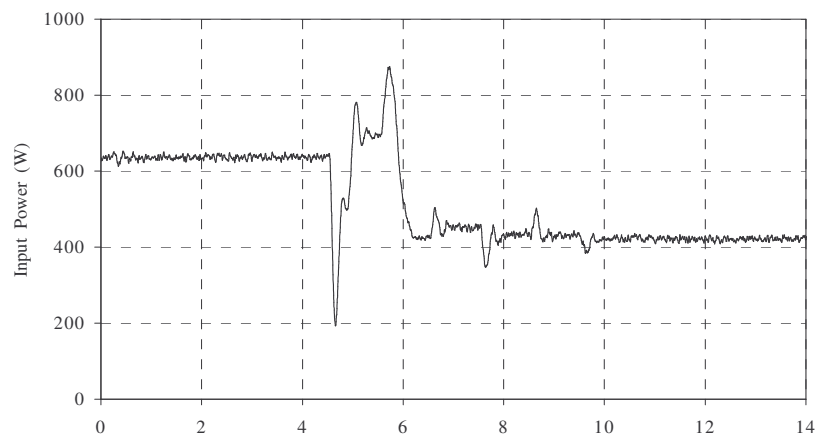

(c)

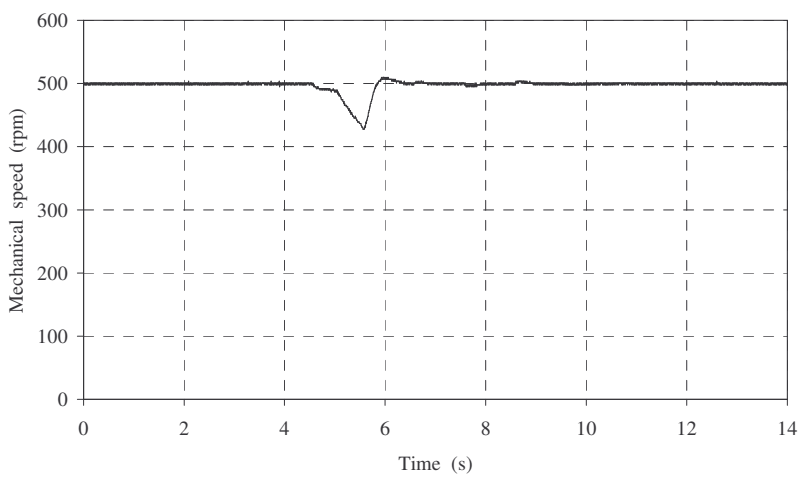

(d)

Fig. 14. Stability problem; Experimental results for full load torque and Nref = 500 rpm: (a) d-axis current Isd, (b) q-axis current Isq, (c) input power Pin, (d) mechanical speed $\mathrm{N}$. 


$\begin{array}{ll}\mathrm{f}: & \text { friction coefficient, } \\ \mathrm{T}: & \text { external load torque, } \\ \text { we: } & \text { electrical speed of the rotor reference frame, } \\ \mathrm{p}: & \text { number of pole pairs, } \\ \text { P: } & \text { motor input power, } \\ \text { Udc: } & \text { dc bus voltage, } \\ \text { Idc: } & \text { dc bus current, } \\ \text { Pin: } & \text { dc bus input power. }\end{array}$

\section{Machine parameters:}

The SynRM used for test is a $230 \mathrm{~V}, 3 \mathrm{~A}, 50 \mathrm{~Hz}, 600 \mathrm{~W}$ four-pole, $1500 \mathrm{rpm}$ with the following parameters:

$$
\begin{array}{lll}
\text { Rs }=7.8 \Omega ; & \text { Lsd }=0.54 \mathrm{H} ; & \text { Lsq }=0.21 \mathrm{H} ; \\
\operatorname{Rrd}=\operatorname{Rrq}=1 \Omega ; & \operatorname{Lrd}=0.1 \mathrm{H} ; & \mathrm{Lrq}=0.046 \mathrm{H} ; \\
\mathrm{Md}=0.153 \mathrm{H} ; & \mathrm{Mq}=0.088 \mathrm{H} ; & \\
\mathrm{J}=0.038 \mathrm{Kg} \cdot \mathrm{m}^{2} ; & \mathrm{f}=0.0029 \mathrm{Nm} /(\mathrm{r} / \mathrm{s}) ;
\end{array}
$$

\section{Reference}

[1] T. A. Lipo, "Synchronous reluctance machines - A viable alternative for AC drives?,” Elec. Mach. Power Syst., vol. 19, pp. 659-671, Nov./Dec. 1991.

[2] A. Vagati, "The synchronous reluctance solution: a new alternative in AC drives," $20^{\text {th }}$ Int. Conf. on Industrial Electronics, Control and Instrumentation, IECON, Bologna, Italy, vol.1, pp. 1-13, 5-9 Sept. 1994

[3] M. J. Kamper, F. S. van der Merwe and S. Williamson "Direct finite element design optimisation of the cageless synchronous machine," IEEE Trans. Energy Convers., vol. 11, no. 3, pp. 547-555, 1996.

[4] T. Matsuo and T. A. Lipo, "Rotor design optimization of synchronous reluctance machine," IEEE Trans. Energy Convers., vol. 9, no. 2, pp. 359-365, 1994.

[5] A. Vagati, A. Canova, M. Chiampi, M. pastorelli and M. Repetto, "Design refinement of synchronous reluctance motors through finiteelement analysis," IEEE Trans. Ind. Applicat., vol. 36, no. 4, pp. 1094$1102,2000$.

[6] A. Chiba, F. Nakamura, T. Fukao and M. Rahman, "Inductances of Cageless Reluctance-Synchronous Machines Having Nonsinusoidal Space Distributions," IEEE Trans. Ind. Applicat., vol. 27, no. 1, pp. 44$51,1991$.

[7] A. Vagati, M. Pastorelli, F. Scapino, and G. Fransceschini, "Impact of cross saturation in synchronous reluctance motor of the transverselaminated type," IEEE. Trans. Ind. Applicat., vol. 36, no. 4, pp. 10391046, 2000

[8] E. Levi, "State-space d-q axis models of saturated salient pole synchronous machines," Proc. Inst. Elect. Eng., vol. 145, pt. B, no. 3, pp. 206-216, 1998.

[9] M. G. Jovanovic, and R. E. Betz, "Optimal torque controller for synchronous reluctance motors," IEEE Trans. Energy Convers., vol. 14, no. 4, pp. 1088-1093, 1999.

[10] L. Xu, X. Xu, T. A. Lipo, and D. W. Novotny, "Vector control of a synchronous reluctance motor including saturation and iron loss," IEEE. Trans. Ind. Applicat., vol. 27, no. 5, pp. 977-985, 1991.

[11] T. Lubin, H. Razik and A. Rezzoug, "Magnetic saturation effects on the control of a synchronous reluctance machine,". IEEE Trans. Energy Convers., vol. 17, no. 3, pp. 35 6-362, 2002.

[12] A. Kusko and D. Galler, "Control means for minimization of losses in ac and dc motor drives," IEEE. Trans. Ind. Applicat., vol. 19, pp. 561-570, July/Aug. 1983.

[13] F. Fernandez-Bernal, A. Garcia-Cerrada, and R. Faure, "Model-based loss minimization for $\mathrm{DC}$ and $\mathrm{AC}$ vector-controlled motors including core saturation," IEEE. Trans. Ind. Applicat., vol. 36, pp. 755-763, May/June 2000

[14] F. Abrahamsen, F. Blaabjerg, J. K. Pedersen, P. Z. Grabowski, and P. Thogersen, "On the energy optimized control of standard and highefficiency induction motors in CT and HVAC applications," IEEE. Trans. Ind. Applicat., vol. 347, pp. 822-831, July/Aug. 1998.
[15] I. Kioskeredis and M. Margaris, "Loss minimization in induction motor adjustable speed drives," IEEE. Trans. Ind. Electron., vol. 43, pp. 226231, Feb. 1996

[16] I. Kioskeridis and C. Mademlis, "Energy efficiency optimisation in synchronous reluctance motor drives," Proc. Inst. Elect. Eng., vol. 150, pt. B, no. 2, pp. 201-209, 2003.

[17] D. S. Kirschen, D. W. Novotny, and T. A. Lipo, "On-line efficiency optimization of a variable frequency induction motor drive," IEEE. Trans. Ind. Applicat., vol. 21, pp. 610-615, May/June 1985.

[18] T. Matsuo, A. El-Antably, and T. A. Lipo, "A new control strategy for optimum-efficiency operation of a synchronous reluctance motor," IEEE. Trans. Ind. Applicat., vol. 33, pp. 1146-1153, Sept./Oct. 1997.

[19] G. K. Kim, I. J. Ha, and M. S. Ko, "Control of induction motors for both high dynamic performance and high power efficiency," IEEE. Trans. Ind. Electron., vol. 39, pp. 323-333, Aug. 1992.

[20] G. C. D. Sousa, B. K. Bose, and J. G. Cleland, "A fuzzy logic based online efficiency optimization control of an indirect vector-controlled induction motor drive," IEEE. Trans. Ind. Electron., vol. 42, pp. 192198, Apr. 1995.

[21] C-M. Ta and Y. Hori, "Convergence improvement of efficiencyoptimized control of induction motor drives," IEEE. Trans. Ind. Applicat., vol. 37, pp. 1746-1753, Nov./Dec. 2001.

[22] J. Kowalik and M. R. Osborne, Methods for unconstrained optimization problems. American Elsevier Publishing Company, Inc., 1968

\section{Biographie}

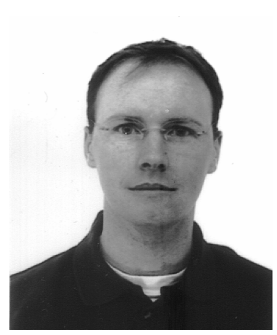

Thierry Lubin was born in Sedan, France, on January 11,1970 . He received the M. Sc. Degrees from the University of Paris 6, France in 1994 and the Ph.D degree from the University of Nancy 1, France in 2003. Dr. Lubin is actually a research associate with the Groupe de Recherche en Electrotechnique et Electronique de Nancy. His research interests include electrical machine, modeling and control.

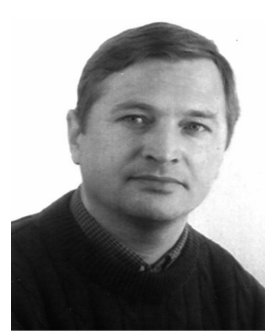

Hubert Razik received the Ph.D. degree from the Polytechnic Institute of Lorraine in Electrical Engineering, Nancy, France, in 1991. He joined the Groupe de Recherche en Electrotechnique et Electronique de Nancy in 1993. He currently works as a lecturer in the University Henri Poincaré. His research interests are control of electrical machines, fuzzy logic, neural networks and genetic algorithms.

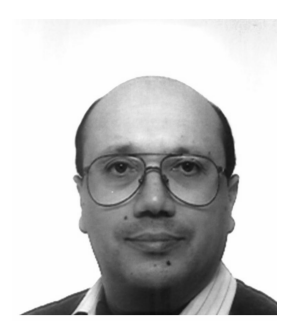

Abderrezak Rezzoug is Professor in Electrical Engineering at the University Henri Poincaré, Nancy, France. As the head of the Groupe de Recherche en Electrotechnique et Electronique de Nancy, his main subjects of research concern electrical machines, their identification, diagnosis and control, and superconducting applications. 